Tropical Journal of Pharmaceutical Research April 2010; 9 (2): 157-163

(C) Pharmacotherapy Group,

Faculty of Pharmacy, University of Benin,

Benin City, 300001 Nigeria.

All rights reserved.

Research Article

Available online at http://www.tjpr.org

\title{
Hepatoprotective Effect of Adenema hyssopifolium G. Don (Gentianaceae) in Carbon Tetrachloride-Induced Hepatotoxicity in Rats
}

\author{
A Rajasekaran ${ }^{1 *}, \mathbf{R}$ Arivukkarasu ${ }^{2}$ and S Murugesh ${ }^{3}$ \\ ${ }^{1} \mathrm{KMCH}$ College of Pharmacy, Coimbatore, ${ }^{2}$ S.B.College of Pharmacy, Sivakasi, ${ }^{3}$ Sri Nandanam College of \\ Engineering and Technology, Vellore, India.
}

\begin{abstract}
Purpose: The effects of oral administration of ethyl acetate, ethanol and aqueous extracts of Adenema hyssopifolium G.Don (Gentianaceae) on carbon tetrachloride-induced liver disorders were investigated. Methods: Rats were individually treated daily with 300 and $600 \mathrm{mg} / \mathrm{kg}$ dose of either ethyl acetate, ethanol or aqueous extracts of $A$. hyssopifolium, respectively, following induction of liver damage with the hepatotoxin, carbon tetrachloride. The hepatoprotective activity of the extracts was assessed by estimating the levels of serum aspartate aminotransferase (ASAT), alanine aminotransferase (ALAT), alkaline phosphatase $(A L P)$ and total bilirubin (TBL) in the rats. Silymarin was used as the reference hepatoprotective agent. Acute toxicity test on the extracts in male mice was also carried out.

Results: At doses of 300 and $600 \mathrm{mg} / \mathrm{kg}$ p.o., the ethyl acetate and ethanol extracts showed significant $(p<0.001$ and $p<0.01)$ dose-dependent hepatoprotective activity, showing decreases in serum levels of ASAT, ALAT, ALP and TBL. The aqueous extract, however, did not exert any significant effect on hepatoprotective activity. All three extracts, up to a dose of $3000 \mathrm{mg} / \mathrm{kg} \mathrm{p.o.} \mathrm{each,} \mathrm{did} \mathrm{not} \mathrm{cause}$ mortality in the acute toxicity test.

Conclusion: The ethyl acetate and ethanol extracts showed significant hepatoprotective activity when compared to untreated (normal) control group while the aqueous extract did not. The active extracts could find future use in countering hepatic damage.
\end{abstract}

Keywords: Hepatoprotection; Iridoid glycosides; Hepatotoxicity. 


\section{INTRODUCTION}

Adenema hyssopifolium G.Don (Gentianaceae) is a slender perennial herb of great medicinal value in India [1]. It is widely used as a substitute for Swertia chirayita Ham.Ex Wall and is also used in folk medicine for the treatment of diabetes mellitus in Western and Southern India [2]. Ethnomedical studies in north Gujarat (India) also reveal the use of the hot aqueous extract of the entire plant of Adenema hyssopifolium by tribal inhabitants for the treatment of diabetes, fever, stomach ache, dyspepsia and for malaria in the interior part of Gujarat [3]. The extracts of the plant are used in Indian Medicine to treat cardiac dropsy, rheumatism and certain mental disorders.

Seven flavonoids have been isolated from the ethanol extract of the entire plant, including apigenin, genkwanin, isovitexin, swertisin and $5-0-\beta-D-$ glucoside [4]. The iridoid glycoside, swertiamarin, was reported to produce central nervous system depressant [5]. A monoterpene alkaloid was reported in this species [6]. Gentiocrucine was shown to be a mixture of three compounds (I, II and III) and erythrocentaurin [7]. Betuline, a triterpene sapogenin, was isolated by earlier workers [8].

The methanol extract of the entire plant has been reported to show protective activity against Dalton's ascitic lymphoma in Swiss albino mice [9].. To the best of our knowledge, no work on the hepatoprotective activity of the ethyl acetate, ethanol and aqueous extracts of Adenema hyssopifolium in carbon tetrachloride-induced liver damage in animals has been reported. Therefore, the present study was undertaken to evaluate the hepatoprotective ability of Adenema hyssopifolium in rats.

\section{EXPERIMENTAL}

\section{Collection, identification and extraction of the plant material}

The entire plant of Adenema hyssopifolium G. Don was collected in September 2004 from in and around Madurai, Tamilnadu, India. The plant was identified and authenticated by Dr D Stephen, a taxonomist at American College, Madurai, India. A voucher specimen ((R.A. no.11/04) was preserved at the herbarium of the Department of Pharmacognosy, Arulmigu Kalasalingam College of Pharmacy, Coimbatore, India for future reference. The entire plant, including the roots, were washed well with water, air-dried for 10 days under controlled temperature $\left(37 \pm 1^{\circ} \mathrm{C}\right)$, pulverized, passed through a $420 \mu$ sieve and stored in an air-tight container until further use.

A quantity $(1.3 \mathrm{~kg})$ was then subjected to maceration with $3500 \mathrm{ml}$ of either ethyl acetate aor $90 \%$ ethanol at room temperature. The extracts were collected and evaporated to dryness under reduced pressure in a rotary evaporator (Eyele, Japan) at $40-45{ }^{\circ} \mathrm{C}$ to give yields of ethyl acetate and ethanol extracts of 10.36 and $14.72 \% \mathrm{w} / \mathrm{w}$, respectively. Also, the coarse material $(600 \mathrm{~g})$ of the entire plant was soaked in sufficient warm water for $30 \mathrm{~min}$ in a clay pot. Thereafter, the contents were boiled for 45 minutes while constantly stirring the contents.and then strained to obtain a decoction [10]. .

\section{Preliminary phytochemical screening}

Preliminary phytochemical screening was carried out by using standard procedures, as described by Kokate [11] and Harborne [12].

\section{Experimental animals}

Swiss male mice (20 - $25 \mathrm{~g})$ and albino adult Wister male rats $(150-200 \mathrm{~g})$ were obtained from the animal house of Pharmacology Department, Arulmigu Kalasalingam College 
of Pharmacy Tamilnadu, India. The study protocol was approved by the institutional animal ethics committee, Committee for the Purpose of Control and Supervision on Animals (CPCSEA), New Delhi, India, as per approval no. $509 / 01 / \mathrm{C} / \mathrm{CPCSEA}$ of $10^{\text {th }}$ July 2002. The animals were housed in plastic cages $(47 \times 34 \times 18 \mathrm{~cm})$ in an air-conditioned environment with 10 cage and 6/cage for mice and rats, respectively. The floor of the cages was lined with saw dust which was renewed every $48 \mathrm{~h}$, and the animals were fed standard pellet diet from Kamadenu Enterprises, Bangalore, India. The animals also had access to water ad libitum.

\section{Acute toxicity test}

Male mice were divided into twenty two groups of ten animals each. The control group received $0.5 \mathrm{ml}$ of $0.5 \% \mathrm{w} / \mathrm{v}$ sodium carboxymethylcellulose orally. The other groups received either 100, 200, 400, 800, 1000,2000 or $3000 \mathrm{mg} / \mathrm{kg}$ of either ethyl acetate or ethanol extract in $0.5 \%$ sodium carboxymethylcellulose orally. Immediately after dosing, the animals were observed continuously for the first $4 \mathrm{~h}$ for behavior, occasionally up to the $6^{\text {th }} \mathrm{h}$, and then kept for up to 14 days post-treatment in order to observe for any toxic symptoms and mortality.

\section{Hepatoprotective test}

The animals were divided in to nine groups of six animals each and labeled (Groups $F_{1}$ to $\left.F_{9}\right)$. Group I $\left(F_{1}\right)$ served as normal control and received sterile olive oil (vehicle) $1 \mathrm{ml} / \mathrm{kg}$ ( p.o). Group II $\left(\mathrm{F}_{2}\right)$ animals constituted the hepatotoxic group, and received $\mathrm{CCl}_{4}$ suspended in sterile olive oil $(1: 1 \mathrm{v} / \mathrm{v}, 2 \mathrm{ml} / \mathrm{kg}$, i.p.) every $72 \mathrm{~h}$ for 10 days. Group III $\left(F_{3}\right)$ received standard drug silymarin $100 \mathrm{mg} / \mathrm{kg}$ (p.o.) for 10 days and $\mathrm{CCl}_{4}$ suspended in sterile olive oil (1:1 v/v, $2 \mathrm{ml} / \mathrm{kg}$,ip). Groups IV - IX $\left(F_{4}-F_{9}\right)$ received ethyl acetate, ethanol or aqueous extract (300 or $600 \mathrm{mg} / \mathrm{kg} /$ day) suspended in $0.5 \%$ sodium carboxymethylcellulose for 10 days and $\mathrm{CCl}_{4}$ suspended in sterile olive oil $(1: 1 \mathrm{v} / \mathrm{v}, 2 \mathrm{ml} / \mathrm{kg}$, ip).

At the end of the experimental period, the rats were fasted overnight and sacrificed by ether anesthesia. Blood and liver samples were collected for biochemical and histological studies.

\section{Assessment of liver functions}

The biochemical parameters, aspartate aminotransferase (ASAT) and alanine aminotransferase (ALAT), were analyzed using ASAT and ALAT kits (Span Diagnostics Private Ltd, Surat, Ltd), respectively [13]. Alkaline phosphatase (ALP) and total bilirubin (TBL) were analyzed using a commercial enzyme kit (Crest Biosystems, Goa, India) [14]. The mean values ( \pm SEM) were computed for each parameter.

\section{Histopathological studies}

Paraffin sections (7 $\mu \mathrm{m}$ thick) of buffered formalin-fixed liver samples were stained with hematoxylin-eosin (which stains the nuclei blue and the cytoplasm pink) to study the liver histological structure of the control and treated rats.

\section{Statistical analysis}

For determination of significant inter-group differences, each parameter was analyzed separately and one way analysis of variance was carried out. Dunnet's test was used for individual comparisons. The $p<0.05$ or less considered statistically significant.

\section{RESULTS}

Preliminary phytochemical screening revealed the presence of flavonoids, aminoacids, iridoid glycosides, steroids and phenolic compounds in ethyl acetate extract. Sugars, iridoid glycosides, flavonoids, phenolic compounds, amino acids and tannins were present in ethanol extract. Aqueous extract showed the presence of 
sugars, trace amounts of phenolic compounds and tannins (Table 1). All three extracts of $A$. hyssopifolium, at a dose of $3000 \mathrm{mg} / \mathrm{kg}$ p.o., did not produce any mortality. Consequently, $1 / 10^{\text {th }}$ and $1 / 5^{\text {th }}$ of this dose (i.e., $300 \mathrm{mg} / \mathrm{kg}$ and $600 \mathrm{mg} / \mathrm{kg}$, p.o., respectively) were used for the pharmacological screening [15]. Among the various extracts tested for hepatoprotective activity, ethyl acetate extract $\left(F_{4}\right.$ and $\left.F_{5}\right)$ and ethanol extract $\left(F_{6}-F_{7}\right)$ exhibited a marked protective effect while the decoction (aqueous extract) showed less effects. The effect of the ethyl acetate extract $(600 \mathrm{mg} / \mathrm{kg})$ was comparable to that of the standard drug, silymarin. As shown in Table 2, treatment with the ethyl acetate extract produced significant decreases in serum levels of ASAT, ALAT, ALP and TBL $(P<0.001)$, compared with the group that was treated only with carbon tetrachloride.

Table 1: Preliminary phytochemical analysis of entire plant extract of Adenema hyssopifolium

\begin{tabular}{lccc}
\hline Constituents & $\begin{array}{c}\text { Ethyl } \\
\text { acetate } \\
\text { extract }\end{array}$ & $\begin{array}{c}\text { Ethanol } \\
\text { extract }\end{array}$ & $\begin{array}{l}\text { Aqueous } \\
\text { extract }\end{array}$ \\
\hline Alkaloids & 0 & 0 & 0 \\
Amino acids & + & + & 0 \\
Anthraquinone & 0 & 0 & 0 \\
glycosides & 0 & 0 & 0 \\
Coumarins & ++ & ++ & \pm \\
Flavonoids & 0 & 0 & 0 \\
Oils & + & ++ & \pm \\
Phenolic & & & \\
groups & ++ & ++ & + \\
Iridoid & 0 & \pm & \pm \\
glycosides & + & 0 & 0 \\
Saponins & 0 & ++ & ++ \\
Steroids & 0 & + & \pm \\
Sugars & 0 & 0 & 0 \\
Tannins & 0 & 0 & 0 \\
Triterpens & Cardiac & 0 & \\
glycosides & 0 & & ++ \\
\hline
\end{tabular}

$+=$ Present,$++=$ abundant,$\underline{\underline{t}}=$ traces, $0=$ absent

\section{DISCUSSION}

Administration of $\mathrm{CCl}_{4}$ caused liver damage due to the free radical $\mathrm{CCl}^{*}{ }_{3}$ formed from
$\mathrm{CCl}_{4}$ by the activation of NADPH Cyt-P450 system of liver endoplasmic reticulum.[16]. This leads to functional and morphologic changes in the cell membrane, resulting in leakage of hepatic enzymes. Compared to other toxins, $\mathrm{CCl}_{4}$ is known to cause hepatic damage with a marked increase in blood serum transaminases and phosphatase activity [17]. $\mathrm{CCl}_{4}$, an extensively studied liver toxicant, and its metabolites, such as trichloromethyl peroxy radical $\left(\mathrm{CCl}_{3}{ }^{*} \mathrm{O}_{2}{ }^{-}\right)$, are known to be involved in the pathogensis of liver damage. The oxidation of fatty acids by free trichloromethyl radical $\left(\mathrm{CCl}^{*}{ }_{3}\right)$ liberates lipid peroxides. [18].

The current study also confirmed these effects of $\mathrm{CCl}_{4}$ toxicity, as indicated by marked increases in serum hepatic enzymes. Indeed, the levels of all the marker enzymes increased significantly in Group II $\left(F_{2}\right)$ rats after $\mathrm{CCl}_{4}$ administration ( $\mathrm{p}<0.001$ ) but ethyl acetate extract treatment $(600 \mathrm{mg} / \mathrm{kg})$ caused significant decreases in the activities of all these enzymes. Thus, our findings support the reported therapeutic use of this plant in traditional medicine for liver ailments and jaundice.

Various flavonoids and iridoid glycosides are reported to be present in the whole plant of Adenema hyssopifolium $G$. Don and they probably play a contributory role in hepatoprotective action and the plant's antioxidant potential [19]. Another important constituent, swertiamarin, which is an iridoid glycoside, may also play an important role in this respect. Furthermore, it has been suggested that iridoid glycoside in certain plants is a critical compound in hepatoprotective activity [20]. The protective activity of aucubin, an iridoid glycoside, against carbon tetrachloride-induced liver damage in mice has been reported [21]. The iridoid glycoside, kutkin, and its glycoside mixtures have also been found to exert hepatoprotective activity. Aucubin derived from traditional medicine was said to possess liver protective activity [22,23]. 
Table 2: Effect of the extracts of Adenema hyssopifolium on hepatotoxicity induced by carbon tetrachloride

\begin{tabular}{|c|c|c|c|c|c|}
\hline Group & Group/treatment & $\begin{array}{l}\text { ALAT } \\
\text { (IU/L) }\end{array}$ & $\begin{array}{l}\text { ASAT } \\
\text { (IU/L) }\end{array}$ & $\begin{array}{c}\text { ALP } \\
\text { (KA units) }\end{array}$ & $\begin{array}{c}\text { Total bilirubin } \\
\left(\mathrm{mg} \mathrm{dL}^{-1}\right)\end{array}$ \\
\hline $\mathrm{F} 1$ & $\begin{array}{l}\mathrm{Na} \text { CMC } \\
\text { (Control) }\end{array}$ & $61.8 \pm 1.2$ & $44.0 \pm 1.0$ & $37.7 \pm 0.6$ & $0.8 \pm 0.0$ \\
\hline $\begin{array}{l}\text { F2 } \\
\text { F3 }\end{array}$ & $\begin{array}{l}\mathrm{CCl}_{4} \text { - treated } \\
\text { Silymarin } 100 \mathrm{mg} / \mathrm{kg}\end{array}$ & $\begin{array}{l}93.0 \pm 1.7 \\
62.5 \pm 2.8^{\mathrm{a}}\end{array}$ & $\begin{array}{l}101.0 \pm 0.8 \\
51.5 \pm 3.2^{\mathrm{a}}\end{array}$ & $\begin{array}{l}83.3 \pm 1.1 \\
42.0 \pm 2.8^{a}\end{array}$ & $\begin{array}{l}9.3 \pm 0.2 \\
1.12 \pm 0.0^{a}\end{array}$ \\
\hline F4 & $\begin{array}{l}\text { Ethyl acetate extract } \\
300 \mathrm{mg} / \mathrm{kg}\end{array}$ & $78.8 \pm 1.8^{a}$ & $90.6 \pm 2.1^{\mathrm{a}}$ & $59.3 \pm 0.8^{a}$ & $5.78 \pm 0.1^{b}$ \\
\hline F5 & $\begin{array}{l}\text { Ethyl acetate extract } \\
600 \mathrm{mg} / \mathrm{kg}\end{array}$ & $64.0 \pm 3.7^{\mathrm{a}}$ & $57.1 \pm 2.5^{a}$ & $43.8 \pm 1.7^{a}$ & $3.71 \pm 0.0^{a}$ \\
\hline F6 & $\begin{array}{l}\text { Ethanol extract } 300 \\
\mathrm{mg} / \mathrm{kg}\end{array}$ & $84.5 \pm 1.5^{b}$ & $73.1 \pm 1.7^{b}$ & $69.3 \pm 1.0^{b}$ & $6.2 \pm 0.3^{b}$ \\
\hline F7 & $\begin{array}{l}\text { Ethanol extract } 600 \\
\mathrm{mg} / \mathrm{kg}\end{array}$ & $80.1 \pm 3.2^{a}$ & $67.6 \pm 1.2^{a}$ & $62.3 \pm 1.3^{\mathrm{a}}$ & $5.83 \pm 0.1^{a}$ \\
\hline F8 & $\begin{array}{l}\text { Aqueous extract } \\
300 \mathrm{mg} / \mathrm{kg}\end{array}$ & $88.2 \pm 2.8^{c}$ & $88.6 \pm 1.1^{c}$ & $71.6 \pm 1.1^{c}$ & $7.06 \pm 0.1^{c}$ \\
\hline F9 & $\begin{array}{l}\text { Aqueous extract } 600 \\
\mathrm{mg} / \mathrm{kg}\end{array}$ & $84.1 \pm 1.4^{b}$ & $83.5 \pm 1.0^{b}$ & $73.0 \pm 2.7^{b}$ & $6.46 \pm 0.1^{b}$ \\
\hline
\end{tabular}

Values are mean $\pm S E ; n=6$ in each group ; ${ }^{a} p<0.001$ compared to the corresponding value for carbon tetrachloride group; ${ }^{b} p<0.01$ compared to the corresponding value for carbon tetrachloride group; ${ }^{c} p<0.1$, not significant.

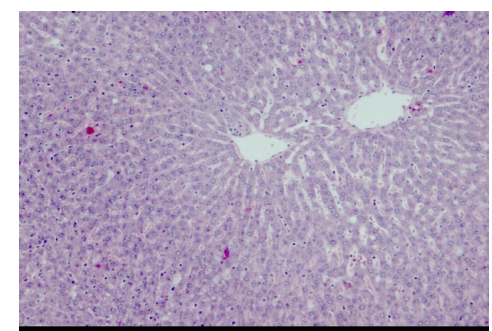

Fig 1(a): Normal healthy central vein and normal liver, normal parenchymal cells

Sections showing structure of liver with sheets of hepatocytes arranged around central vein. Sinusoids in between the rows of hepatocytes appear normal.

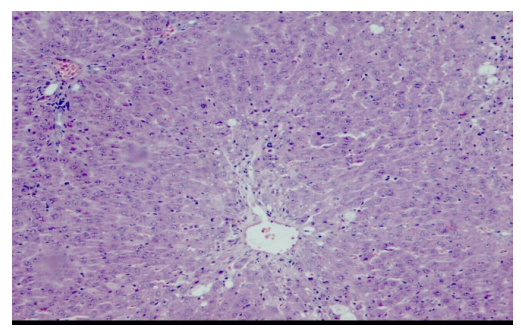

Fig 1(b): $\mathrm{CCl}_{4}$-induced liver damage

Section showing liver parenchyma with central vein and many hepatocytes showing extensive fatty change. Portal tract showing inflammatory infiltrate.

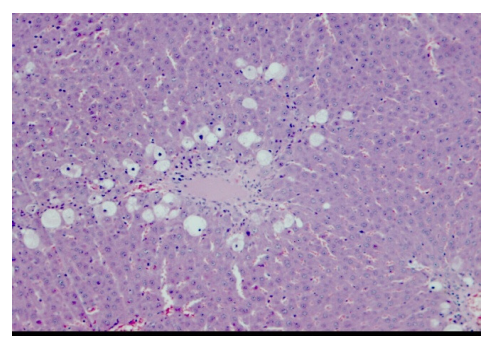

Fig 1(c): Silymarin-treated liver

Section showing liver parenchyma with sheets of hepatocytes, around central vein; portal tract showing mild inflammatory infiltrate; occasional hepatocytes showing fatty change

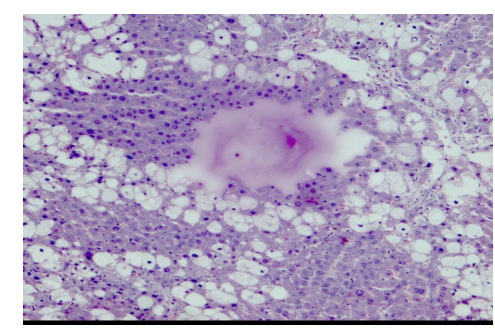

Fig 1(d): Liver-treated with ethyl acetate (600 $\mathrm{mg} / \mathrm{kg}$ ) of Adenema hyssopifolium

Section showing portal tract with inflammatory infiltrate and fatty change 
Rajasekaran et al

\section{CONCLUSION}

The results of this investigation indicate that the ethanol and ethyl acetate extracts of Adenema hyssopifolium contain pharmacologically active substances with hepatoprotective properties. These attributes provide the rationale for the use of Adenema hyssopifolium in liver disorders by traditional healers in India. Further research is needed to fractionate the extracts and to isolate the molecule(s) responsible for the hepatoprotective activity.

\section{ACKNOWLEDGEMENT}

The authors are grateful to $\mathrm{Dr} \mathrm{R}$ Usha Rani (Consultant Pathologist), Bose Clinical Laboratory, Madurai,Tamilnadu, India, for her assistance in the histological work

\section{REFERENCES}

1. Grover JK, Yadav S, Vats V. Medicinal plants of India with antidiabetic potential. J. Ethnopharmacol. 2002; 81: 81-100.

2. Manisha M, Priyanjali D, Jayant L, Saroj G, Thomas Paul AD. Indian herbs and herbal drugs used for the treatment of diabetes. J Clin Biochem Nutr. 2007; 4: 163-173.

3. Goyal RK, Vishwakarma SL. Hepatoprotective activity of Enicostemma littorale in $\mathrm{CCl}_{4}$ - induced liver damage. J Nat Rem. 2004; 4: 120-126.

4. Ghosal S, Jaiswal DK. Chemical constituents of Gentianaceae XXVIII: Flavanoids of Enicostemma hyssopifolium (wild) verd. J Pharm Sci. 2006; 69: 53-56.

5. Ghosal S, Chaudhuri RK, Singh AK, Sharma V. Chemical constituents of Gentianaceae XX:

Natural occurance of (-) loliolide in Canscora decussate. J Pharm Sci.1976; 65: 1549-1551.

6. Chaudhuri RK, Singh AK, Ghosal S. Chemical constituents of Gentianaceae XVIII: Structure of Enicoflavine -Monoterpene alkaloid from Enicostemma hyssopifolium. Chem Ind. 1975; 3: 127-128.

7. Ghosal S, Singh AK, Sharma PV, Chaudhuri RK. Chemical Constituents of Gentianaceae IX: Natural Occurance of erythrocentuarin in Enicostemma hyssopifolium and swertalawii. $J$ Pharm Sci. 1974; 63: 944- 945.

8. Desai PD, Ganguly AK, Govindachari TR, Joshi BS, Kamal VN, Manmade AH, Mohamed $P A$, Nagle SK, Nayak RH, Saksena AK, Sathe SS, Viswanathan N, Chemical investigation of some Indian medicinal plants. Part II. Ind J hem.1996; 4: 457-459.

9. Kavimani S, Manisenthilkumar KT. Effect of methanolic extract of Enicostemma littorale on Dalton's ascitic lymphoma. J. Ethnopharmacol. 2000; 71: 349-352.

10. Juliana AS, Zeila PL, Hélio K, Alba RM, Souza B, Lourdes CS4, Wagner $V$, Clélia AHL. Polyphenols with Antiulcerogenic Action from Aqueous Decoction of Mango Leaves

(Mangifera indica L.) Molecules. 2009; 14: 10981110.

11. Kokate CK. In: Practical Pharmacognosy, $f^{\text {st }}$ ed., Vallabh Prakashan, New Delhi, 1986, 111.

12. Harbone JB. Methods of extraction and isolation, In: Phytochemical Methods, Chapman \& Hall, London, 1998, 60-66.

13. Reitmann S, Frankel S. A colorimetric method for the determination of serum oxaloacetic and glutamic pyruvic transminases. $A m \mathrm{~J} C l i$ Pathol. 1957; 28: 56-63.

14. Kind PRM, King EJ. In-vitro determination of serum alkaline phosphatase. J.Clin Pathol. 1972; 7: 321-322.

15. Sharada AC, Soloman FE, Umadevi P. Toxicity of Withania somnifera root extract in rats and mice. Int J Pharmacog. 1993; 3: 204-205.

16. Nasrin A, Iran R, Amir M. Hepatoprotective Activity of Capparis spinosa Root Bark Against $\mathrm{CCl}_{4}$ Induced Hepatic Damage in Mice. Iranian Journal of Pharmaceutical Research 2007, 6: 285-290.

17. Shabbeer J, Radhey SS, Sushil KS. Hepatoprotective Effect of Crude Extract and Isolated Lignans of Justicia simplex. against $\mathrm{CCl}_{4}$ Induced Hepatotoxicity. Pharm Biol. 2007; 45: 274-277.

18. Kazuo N. Carbon tetrachloride-induced alterations in hepatic glutathione and ascorbic acid contents in mice fed a diet containing ascorbate esters. Arch Pharmacol. 1993; 67: 686- 690 .

19. Al-Qarawi AA, Mousa HM, Ali BH, Abdel-Rahman H, El-Mougy SA. Protective effect of extracts from dates (Phoenix dactylifera L.) on carbon tetrachloride- induced hepatotoxicity in rats. Intern. J. Appl. Res. Vet. Med., 2004; 2: 176180.

20. Chanchal KR, Jagadish VK, Mohammed A. Hepatoprotective activity of Psidium guajava Linn leaf extract . Indian J Exptal Biol. 2006; 44: 305311.

21. Wang $H$, Wu FH, Xiong $F, W u J J$, Zhang $L Y$, Ye WC, Li $P$, Zhao SX. Iridoids from Neopicrorhiza scrophulariiflora and their hepatoprotective activities in vitro. Chem Pharm Bull 2006; 54: 1144-1149.

22. Chang IM, Ryn JC, Park YC, Yun HS, Yang KH. Protective activities of aucubin against $\mathrm{CCl}_{4}$ - induced liver damage in mice. Drug Chem Toxicol. 1983; 6:443-453. 


\section{Rajasekaran et al}

23. Chang IM. Liver protective activities of aucubin derived from traditional oriental medicine. Res Commun Mol Pathol Pharmacol. 1998; 102: 189-204. 